\title{
A and D Ointment
}

National Cancer Institute

\section{Source}

National Cancer Institute. A and D Ointment. NCI Thesaurus. Code C28794.

A topical preparation containing fat-soluble vitamins $A$ and $D$ usually in a lanolinpetrolatum base, A and D Ointment promotes healing of minor burns, rashes, sunburn, skin irritations, and acne; and prevents diaper rash. Vitamin A is essential for diverse cellular functions, immune system functions, and maintenance of mucous membranes, while vitamin D regulates calcium and phosphorous metabolism. ( $\mathrm{NCI04)}$ 